${ }^{\circ}$ Copyright by Pusat Riset dan Pengembangan Produk Halal Universitas Airlangga

\title{
THE CONCEPT OF HALAL AND THAYYIB AND ITS IMPLEMENTATION IN INDONESIA
}

\section{KONSEP HALAL DAN THAYYIB BESERTA IMPLEMENTASINYA DI INDONESIA}

\author{
Muhammad Cholil Nafis ${ }^{1}$ \\ ${ }^{1}$ Head of the Department of Advocacy at the Council of Indonesian Ulema, \\ Lecturer at Universitas Islam Negeri Syarif Hidayatullah Jakarta \\ *email: cholil.nafis@uinjkt.ac.id
}

\begin{abstract}
The issue of halal and haram is regarded by Muslims as the basis concept. The word halal is derived from Arabic word, permissibility (in the sense of what is permitted in the Shariah). For Muslims, the basis of every action must be worship, which is worshipping to God Almighty. The eating activity is also a means of worship with rules and procedures according to the Sharia. The Holy Quran says eating is not just enough for halal but it should be thayyib. Therefore, the guarantee of halal products is important. The tremendous advances in science and technology in the fields of food, medicine and cosmetics are growing. This condition affects many things in the processing and use of basic ingredients. In order to keep Muslim's food from haram contaminations, espicially from basic ingredients, the Indonesia Ulema Council (MUI) has been the pioneer in obtaining Halal certification. In Indonesia, the efforts to award Halal certificates have taken a quarter of a century. MUI has been granted a Halal certificate to ensure the nation's access to food, beverages and halal materials. MUI has also established the standards of halal according to Islamic law. The examination and study are then conducted to issue a fatwa and then a Halal certificate is issued. Halal certification process was not maximized in Indonesia because politics was not integrated and facilities and infrastructure were inadequate.
\end{abstract}

Keyword: halal concept, product guarantee, halal certification

\begin{abstract}
Permaslahan halal dan haram merupakan konsep pokok. Kata halal berasal dari kata dalam Bahasa Arab yang bermakna diizinkan (dalam arti apa yang diizinkan dalam syariah). Bagi umat Islam, dasar dari setiap tindakan haruslah ibadah, yaitu menyembah kepada Allah. Kegiatan makan juga merupakan sarana ibadah dengan aturan dan prosedur sesuai dengan syariah. Kitab Suci Al-Qur'an menjelaskan bahwa kegiatan mengkonsumsi sesuatu tidak cukup berhenti pada konsep halal, tetapi juga thayyib. Karena itu, jaminan produk halal menjadi penting. Kemajuan luar biasa dalam sains dan teknologi di bidang makanan, obat-obatan, dan kosmetik terus meningkat. Kondisi ini mempengaruhi banyak hal dalam pengolahan dan penggunaan bahan-bahan dasar. Untuk menjaga makanan muslim dari kontaminasi haram, khususnya dari bahan-bahan dasar, Majelis Ulama Indonesia (MUI) telah menjadi pelopor dalam memperoleh sertifikasi halal. Di Indonesia, upaya untuk memberikan sertifikat halal telah memakan waktu seperempat abad. MUI telah diberikan sertifikat halal untuk memastikan akses negara ke makanan, minuman dan bahan halal. MUI juga telah menetapkan standar halal menurut hukum Islam. Pemeriksaan dan studi dilakukan untuk mengeluarkan fatwa dan kemudian dilanjutkan dengan sertifikat halal. Proses sertifikasi halal di Indonesia masih belum maksimal karena kondisi politik yang tidak terintegrasi dan sarana dan prasarana yang tidak memadai.
\end{abstract}

Keyword: Konsep halal, jaminan produk, sertifikasi halal 


\section{INTRODUCTION}

The issue of halal and haram is regarded by Muslims as the basis of learning Islam for the application of faith. It is advisable for a Muslim to avoid matters of suspicion (syubuhat) in order to ascertain the position according to Islamic law. The purpose of the precaution in work, consumption and use of goods is to ensure that people might become a fully committed Muslim (abid) and wish to be accepted all of act by Allah the Almighty. These things are different for the general public to those who do not comprehend with the teachings of Islam. Often, the halal is just about eating and drinking foods or drinks allowed in Islam. Islam believes that halal includes a broader meaning including behavior, actions, speech, attitudes, clothing, cosmetics, medicines, and so on.The Fuqaha argue that halal and haram are what Allah and His Messenger have said. In this sense, Allah serves the verdict for people by means of His Messenger (al-Saadi on Tayseer Al-Kareem Al-Rahman fee Tafseer Kalaam II-Mannan). It is a matter of assignment to servants, including the provisions of the religion. Allah and His Messenger have the right to prove the rulings, whether it is halal or haram. Yusuf al-Qaradawi said that God put judgments on his servants, so who has proven the verdict is beyond the limits of God.

Based on Mu'jam Lugaah al-Fuqahaa' by Qala'ji and Quneibi, the word halal is derived from permissibility in the sense of what is permitted in the Shariah. al-Jurjani on Ta'rifaat said, halal is conquest. The term is what does not punish the act or launched the Sharia to do. Al-Samani on Qawathi' al-Adillah fi Ushul al-Figh said that haram is what is punishable to do, and halal is what he should do, and jaiz is not punishable by what he does and not rewarded by what he does. Thus, the definition of halal based on Quran and Hadith is very simple and clear. All that is good for the body, mind and soul is halal. On the contrary, everything brings harm (danger) to health: the body, mind and spirit is haram (Tafseer al-Qur'an al-'Adhim). In the Technical Guidelines for Halal Production issued by the Ministry of Religious Affairs, food is a commodity to be consumed or consumed by humans, as well as ingredients used in the production of food and beverages. While halal is permitted according to Islamic teachings.

In conclusion, halal is the thing permitted by Sharia to be implemented, used, or attempted, because it has lost the obstacles that prevent it or the elements it poses by obtaining it well and by compromising between the party, and not through the results of prohibited methods.

\section{THE IDEA OF HALAL AND THOYYIB}

For Muslims, the basis of every action must be worship, which is worshipping to God Almighty. God said: "I did not create the jinn and mankind except to worship" (adz-Dzariat: 56). The eating activity is also a means of worship with rules and procedures according to the Sharia. The Holy Quran says eating is not just enough for halal but it should be good too. This can be seen from several expressions of halal words in several verses of the Qur'an, which are always followed by the words of the good. As I mentioned: "O people, eat of good things in the earth, and do not follow the footsteps of the devil, for he is a clear enemy to you" (al-Baqarah 2: 168). "Eat all that you have done well, and fear Allah, for Allah is Forgiving, Most Merciful' (al- Anfal: 69). "Eat all that Allah has provided you with good solace and thank the grace of God if you worship Him" (an-Nahl: 114). "And eat what Allah has provided you with good solace and fear Allah, with whom you are believers". (al-Maidah: 88)

In these verses the word "Halal" becomes the basis for the order to eat food and drink which are halal and good because not all Halal foods are good. Al-Saadi on Tayseer Al-Kareem Al-Rahman fee Tafseer Kalaam II-Mannan explained from Surat al-Baqarah 168 that the letter from this verse is a call addressed to all human beings, believers and non-believers. Muhammad Ali al-Sabouni on Shafwat al-Tafseer confirmed the verse with the same understanding that the verse is common, meaning that all human beings consume God's justification for them

Imam Malik said that the word good means halal, such as strengthening the word halal. From the point of view of Imam Malik, it is clear that Halal and Tayyib meet in one sense as emphasizing. According to Abu Bakr Ibn al-Arabi, the good is the opposite of the malignant, which means bad, then added the meaning of the good to those concerned: First, what is appropriate for the body or body and feels delicious. Secondly, what God analyzed (al-Arabi on Ahkam al-Qur'an).

Hafiz Ibn Katheer explained that a good word in this verse which is delicious for humans does not harm the body and mind. The good can also be interpreted as good food and drink, containing good nutrients for health if consumed or not cause harmful side effects or harmful to the body.

\footnotetext{
${ }^{\circ}$ Copyright by Pusat Riset dan Pengembangan Produk Halal Journal of Halal Product and Research
} E-ISSN: 2654-9778; P-ISSN: 2654-9409 
The basis of all foods and beverages derived from plants, vegetables, fruits and animals is halal except some of them which have toxin that dangerous for human. The general principle is no prohibition on halal food consumption because of its verdict, everything is originally halal. Al-Quran explains some things which are forbidden. The Almighty said: "He has only forbidden to you dead animals, blood, the flesh of swine, and that which has been dedicated to other than Allah. But whoever is forced [by necessity], neither desiring [it] nor transgressing [its limit], there is no sin upon him. Indeed, Allah is Forgiving and Merciful" (al-Baqarah 173).

They were bodies, blood, pork and slaughtered animals for those who had names other than God, suffocated, beaten, fallen, and ordained, and attacked by wild animals, for animals slaughtered and slaughtered animals given to idols. Haram drink is every types of intoxicating drinks whether processed from halal or non-kosher foods (Abdul Malik Kamal on Fiqhu al-Sunnah li an-Nisaa'). There is a halal food for itself, but sometimes it is haram because of external treatment factors (for others). Halal foods are all halal foods materially. Haram foods are all food that is materially forbidden. As for the halal in how to obtain it is real in finding and obtaining it, not in a manner of haram and not in the wrong way. Because food is sometimes self-permissible, it is haram because of the way it is obtained unlawfully, such as: usury, theft, fraud, bribery, corruption and other illegal acts.

\section{HALAL PRODUCT GUARANTEE}

The 1985 UN Consumer Protection Guidelines (UN) states that "Consumers everywhere, in all countries, have basic social rights." These basic rights are intended to obtain clear, correct and fair information, the right to compensation and the right to basic human needs (Nasution 2001). Therefore, it becomes the fundamental right of the global community to know and obtain food, beverages and goods in accordance with their beliefs and facilitate them by the state. The Constitution of the Republic of Indonesia of 1945 imposes on the State the guarantee of the freedom of every citizen to profess his own religion and worship according to his religion and belief. Therefore, guaranteeing Halal products to Indonesian Muslims is part of the basic rights of the people that must be facilitated by the state because halal consumption and use of Muslims is part of worship. The guarantee of halal products is important given that the tremendous advances in science and technology in the fields of food, medicine and cosmetics are growing. Much has been influenced by the shift in the processing and use of basic materials from what was originally simple and natural to the processing and use of raw materials produced by science.

It should be noted that before the development of fast food processing technology as it is now, the public concept of haram is still a very simple product. The problem of food or drink is halal or haram related only to the presence or absence of substances containing pork or alcohol. Food or drinks that are free of both articles are considered halal. But now, food processing technology has evolved and changed from this perspective because the production of food for consumer goods not only depended on key ingredients, but also required additional ingredients.

The processing of products through the use of scientific and technological progress enables the mixing of Halal and Haram intentionally or unintentionally. Therefore, to know the halal and purity of the product, there is a need for a special study requiring multidisciplinary knowledge, such as knowledge in the fields of food, chemistry, biochemistry, industrial engineering, biology, pharmacy and understanding of Sharia.

Riyaz and Khadry (2004) also stated that in the production of Halal products they must apply the three zero concept, which is free of limits, free of defects and free of risk (Prabowo and Abdur Rahman 2016). This means that raw ingredients should not be contained in the primary and additional materials and products in all production circles, including that impurities must not contaminate the materials needed to produce halal products. Consequently, there should be no products that produce haram (free defects) in view of the large risks incurred by the company if there are claims of prohibited products and correct. If these are applied, there is no risk (risk free) borne by the company.

Ensuring Halal products is important for achieving consumer rights and meeting producers' obligations. Producers must ensure that the production process applies Halal and good production methods, which means that it is true and good to supply raw materials to consumer ready consumption. To ensure this, raw materials must be safe from biological, chemical, physical and haram contaminations. The production process must be made of clean tools and places and avoid uncleanness. The use of additional materials used in production shall also be in accordance with the provisions permitted by it.

In order to keep Muslim's food from haram contaminations from basic ingredients, the Indonesia Ulema Council (MUI) has been the pioneer in obtaining Halal certification. This result

\footnotetext{
${ }^{\circ}$ Copyright by Pusat Riset dan Pengembangan Produk Halal Journal of Halal Product and Research
} E-ISSN: 2654-9778; P-ISSN: 2654-9409 
gained from the moment when the research of Tari Susanto found that there is the existence of Pig products in many food and beverage products. This discovery was published in the Canopy Bulletin in January 1988 and became popular when it was reported by the media. In this case, sales of food and beverage products fell by $80 \%$, leading to a decline in national economic growth and causing Muslim anger in Indonesia. The situation improved after the government approved a Halal certificate issued by the MUI (Girindra 2008).

The MUI has been interested in whether the product contains the basic elements of the haram materials, and not the issue of external factors of haram, which means that this method is incompatible with Islamic law. This means that the consolidated information unit only examines the basic elements of food, beverages, manufactured goods and other uses, but not to examine how goods are obtained.

In the MUI standard, Halal products are products that meet Halal requirements according to Islamic law: (1) Do not contain pigs and pig derived components; (2) Do not contain haram materials such as ingredients derived from human organs, blood, dirt and others; (3) All materials derived from halal animals slaughtered in accordance with Islamic Shariah procedures; (4) All materials derived from Halal animals should be used and slaughtered according to Islamic law, all storage places, treatment facilities, and may not be used for transportation of pigs. If the transfer is preceded by the use of a pig or any other hemp, it must be cleaned in a manner consistent with Islamic law; (5) All foods and beverages that do not contain alcohol (Depag 2003).

In order to ensure the validity of the product, MUI issues declaration (fatwa), the Fatwa can be issued so that Halal certificates can be issued after the examination and scrutiny. Auditors conduct research, audit of factories (companies) that require Halal certification. Tests carried out include: (I) a thorough examination of the materials of the product, whether raw materials or predominant materials; (2) Check the manual on the purchase of the product materials. These materials are then examined in the laboratory, especially for substances suspected of being impure or containing impurity to obtain the result. The results of the examination and audit of the Institute of Food, Drug and Cosmetic Evaluation were then recorded in a record and news event. The record was then presented to the Fatwa Committee of the Ulema Council to decide the verdict (MUI 2008).

In order to ensure the halal of the product that has obtained the certificate of halal, MUI states that if it is found in the future that the product contains items of raw or unclean goods, the Halal certificate issued by the Council of Ulema is cancelled.

In order to ensure product halal, MUI tries to integrate the two concepts into "good halal" in the form of theory and practice. The method of proving that the sentence is valid, whether in the form of medicines, cosmetics, food or drinks, by sending experts to inspect the place of manufacture of products ranging from raw materials to processes and procedures, so that they know exactly what is loaded in the contents of the product from the process of raw materials Cooked, and from the purchase to the goods.

In Indonesia, the efforts to award Halal certificates have taken a quarter of a century. However, in a long period of time, the development was less severe compared to Malaysia and Thailand. Indonesia's competitiveness in the development of the Halal agricultural industry of Southeast Asia is in fifth place, higher than the Philippines alone. Indonesia excels only in market potential factors, Halal certification systems, certification bodies, and availability of raw materials. While the logistics infrastructure, government commitments and policies, and international and domestic advocacy capabilities, Indonesia is located under other countries.

Although there is Act No. 33 of 2014 on Halal Products Assurance, the effectiveness of policy implementation is still relatively low or not implemented. This due to the Halal Products Assurance Agency was not yet operational because government regulations were not final. The implementation of the policy on dealing with Halal food has not been more widely disseminated to society, especially for the food industry as the main producer.

\section{CONCLUSION}

The implementation of the teachings of Islam is related to close to halal implementation and away from haram. Halal is something that is permitted and Haram is something forbidden from God Almighty. Therefore, the existence of obligational obedience is followed by commands which are set by Allah Almighty and away from all forbidden things.

Food, drink and goods in Islam contain elements of worship that are closely related to the problems of halal and haram. Although the Quran describes many things that are essentially taboo for consumption, in practice Indonesia and some countries use Halal certification because they are

\footnotetext{
${ }^{\circ}$ Copyright by Pusat Riset dan Pengembangan Produk Halal Journal of Halal Product and Research
} E-ISSN: 2654-9778; P-ISSN: 2654-9409 
based on the principle of precaution. This is the expectation of the number of manufactured goods that use basic materials or a mixture of nuisance or unclean goods.

Indonesia has participated in the international conventions, the 1945 Constitution and the legislation of the state's counsels. MUI has been granted a Halal certificate to ensure the nation's access to food, beverages and halal materials. MUI has also established the standards of halal according to Islamic law. The examination and study are then conducted to issue a fatwa and then a Halal certificate is issued. Halal certification was not maximized in Indonesia because politics was not integrated and facilities and infrastructure were inadequate.

\section{REFERENCE}

al-Arabi, Abu Bakr Muhammad bin Abdullah Ibn, Ahkam al-Qur'an Volume 2/32. Beirut (KWT): Dar alFikr.

al-Jarjani, Ali Muhammad ibn Ali. 1405. At-Ta'reefat, Tahqiq by Ibrahim al-Abiari, Beirut (KWT): Dar al-Kuttab al-Arabi. Part 1/124

al-Saadi, Abdul Rahman bin Nasser. 2000/1420. Tayseer Al-Kareem Al-Rahman fee Tafseer Kalaam II-Mannan. Part 1 page 288, edition 1. Muassasah al-Risalah

al- Samani, Abi al-Muzaffar Mansour bin Mohammed bin Abdul-Jabbar. Qawathi' al-Adillah fi Ushul alFiqh. Part 1 Page 10. Beirut (KWT): Dar al-Kut al-Ulum.

al-Sabouni, Muhammad Ali, Shafwat al-Tafseer Volume 1/113. Beirut (KWT): Dar al-Fikr.

[Depag] Departemen Agama Republik Indonesia. 2003. Panduan Sertifikat Halal. Jakarta (ID): Departemen Agama.

Girindra A. 2008. LPPOM MUI, dari Sertifikasi menuju Labelisasi Halal. Jakarta (ID): Pustaka Jurnal Halal.

Isma'il, Abi al-Fidaa ibn 'Umar ibn Kharj, 1420/1999. Tafseer al-Qur'an al-'Adhim. Part 1 Page 487. Dar al-Taiba.

Kamal, Abdul Malik bin Sayed Salem. Fiqh al-Sunnah li an-Nisaa': 493.

[MUI] Majelis Ulama Indonesia. 2008. Sistem dan Prosedur Penetapan Fatwa Produk Halal Majelis Ulama Indonesia. Jakarta (ID): MUI.

Nasution Az. 2001. Hukum Perlindungan Konsumen Suatu Pengantar. Yogjakarta (ID): Diadit Media.

Prabowo S, Abd Rahman A. 2016. Sertifikasi halal sektor industri pengolahan hasil pertanian, Forum Penelitian Agro Ekonomi 34(1): 63.

Riaz NM, Chaudry MM. 2004. Halal food production. Florida (US): CRC Press LLC.

Qala'ji MR, Quneibi MS. Mu'jam Lugaah al-Fuqahaa'. Beirut (KWT): Dar al-Kutab al-Arabi, year 1405: $1 / 183$. 